\title{
An Introduction and Various Phytochemical Studies of Cinnamomum Malabatrum: A Brief Review
}

\author{
Mrs. Tirumala Duguta*, Dr. Binoy Varghese cheriyan
}

Mrs. Tirumala Duguta*, Dr. Binoy Varghese cheriyan

Department of Pharmaceutical Chemistry and Analysis, School of Pharmaceutical Sciences, Vels Institute of Science, Technology and Advanced Studies, Pallavaram, Chennai - 600 117, Tamil Nadu, INDIA.

\section{Correspondence}

\section{Mrs. Tirumala Duguta}

Department of Pharmaceutical Chemistry and Analysis, School of Pharmaceutical

Sciences, Vels Institute of Science,

Technology and Advanced Studies

Pallavaram, Chennai - 600 117, Tamil Nadu INDIA.

E-mail: tirumaladuguti@gmail.com

History

- Submission Date: 21-12-2020;

- Review completed: 18-01-2021;

- Accepted Date: 15-02-2021.

DOI : 10.5530/pj.2021.13.101

Article Available online

http://www.phcogj.com/v13/i3

\section{Copyright}

(C) 2021 Phcogi.Com. This is an openaccess article distributed under the terms of the Creative Commons Attribution 4.0 International license.

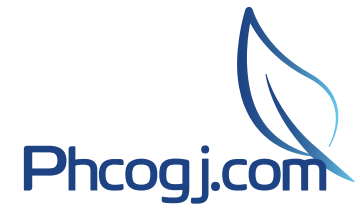

\section{ABSTRACT}

Context: The aim of this research is to find new anticancer drugs from indigenous plant which are potent nontoxic or minimal toxic and to investigate the anticancer activity of Cinnamomum malabatrum plant leaves. Objective: The objective of the present study is to identify selected medicinal plants which possess anticancer activity according to their traditional uses. Materials \& Methods: Cinnamomum malabatrum leaves, extraction method. Results and Discussion: Cinnamon (Cinnamomum malabatrum), the eternal tree of medical science belongs to the Lauraceae family. Cinnamon is one in every of the foremost important spices used daily by people everywhere in the world. Cinnamon primarily contains vital oils and other chemical constituents like Cinnamaldehyde, Cinnamic acid, Cinnamate. These constituents are used in different kinds of diseases they also producing cardiovascular disease lowering compound, used as antioxidant, anti-inflammatory, antidiabetic, antimicrobial, anticancer, lipid-lowering agent, and cardiovascular-disease-lowering compound, cinnamon has also been reported to have activities against cancer, like Parkinson's and Alzheimer's disease. Conclusion: This review illustrates the phytochemical studies prospective.

\section{INTRODUCTION}

Cinnamomum malabatrum is also called as wild cinnamon, country cinnamon and as malabathrum, it belongs to the family Lauraceae, that is endemic to western ghats of India. It can grow up to $15 \mathrm{~m}$ (49ft) tall. It has aromatic leaves are used for culinary and medicinal purpose. It is thought to have been one of the major sources of the medicinal plant leaves known in classical and medieval times as malabathrum (or malobathrum).

Malabar is traditionally used to denote the west coast of southern India forms the present-day state of Kerala and adjoining areas.

The word mala or Malaya means -a mountain in the languages Tamil and Malayalam and Sanskrit. The word 'malabathrum' is thought to have been derived from the Sanskrit tamālapattram, literally meaning "dark-tree leaves". In figure 1 you can see the dark tree leaves of Cinnamomum malabatrum.

\section{TAXONOMY}

\section{Scientific classification}

Botanical name - Cinnamomum malabatrum

Kingdom - Plantae

Clade: Tracheophytes

Clade: Angiosperms

Clade: angolides

Division - Magnoliophyta

Class - Magnoliopsida

Order - Laurales
Family - Lauraceae

Genus - Cinnamomum

Species: C.malabatrum

Binomial name: Cinnamomum

\section{SYNONYMS}

Cinnamomum malabathricum Lukman

Cinnamomum ochraceum Blume

Cinnamomum rheedii Lukman

\section{RELATED SPECIES}

Cassia

Cinnamomumverum

Cinnamomumtamala

Cinnamon

Saigon cinnamon

\section{VERNACULAR NAMES}

English - Country Cinnamon

Hindi - JangliDalchini

Marathi - Dalchinitiki

Tamil - Kattu-karuvappattai

Telugu - Adavilavangapatta

Sanskrit - Tejpatra

Persian - Sazaj-i-Hindi

Malayalam - Karuntoli

Cite this article: Duguta T, Cheriyan BV. An Introduction and Various Phytochemical Studies of Cinnamomum Malabatrum: A Brief Review. Pharmacog J. 2021;13(3): 792-7. 


\section{HABITAT}

Tropical and the subtropical Himalayas, U.P., Eastern Bengal, the Khasia and so the Jaintia Hills, Burma and western ghats in south India. ${ }^{1-3}$

\section{MORPHOLOGY}

The Cinnamomum Malabatrum is moderate evergreen tree, the bark is smooth or slightly longitudinal cracked brown. Leaves are opposite or sub-opposite, elliptic to oblong, glabrous, Colour is in pink when young, 3-nerved from close above the underside almost to the apex. Flowers are long, pale yellowish and fruits ellipsoid.

\section{METHODOLOGY}

The current review was conducted employing an entire and arranged search of the available literature on the medicinal plant cinnamon from 1982 to 2019. The searches were performed using various databases, including Pub Med (http://www.ncbi.nlm.nih.gov/pubmed), Science Direct (http://www.sciencedirect.com/), Scopus (http://www.scopus. com/), Scirus (http://www.scirus.com/), and Google Scholar

\section{TRADITIONAL USES}

In addition to being employed as a spice and flavouring agent, cinnamon is additionally added to flavour chewing gums due to its mouth refreshing effects and skill to urge eliminate bad breath. Cinnamon can even improve the health of the colon, thereby reducing the prospect of carcinoma. $^{2}$

\section{MEDICINAL USES ${ }^{2,4-7}$}

The essential oil obtained from the leaves has been shown to be antibacterial and antifungal. The leaves are carminative. They are used in the treatment of colic and rheumatism. They are sweetish and heating, making them useful in vata, scabies, disease of the anus and rectum, tridosha, piles and heart troubles.An ethanol extraction of the leaves has shown significant anti-inflammatory activity and can be used in the treatment of acute inflammation. ${ }^{8}$

\section{CHEMICAL CONSTITUENTS ${ }^{9}$}

Cinnamomum malabatrum leaves contain chemical composition of cinnamic aldehyde, eugenol, $\beta$-caryophyllene, benzaldehyde, camphor, cadinene, $\alpha$-terpinol, limonene, geraniol, eugenol acetate, ocimene $^{8}, \gamma$-terpinene, benzyl cinnamate, $\beta$-phellandrene and benzyl acetate. The oil from bark contains cinnamaldehydes (70-85\%) as a big constituents. The plant also contain 3,4,5,7- tetra hydroxyl flavones, 3,3,4,5,7-pentahydroxy flavones, kaempferol-3-Osophoroside and quercetin 3-O- rutin.

The constituents of the essential oils of leaf, petiole, shoot and terminal shoot of Cinnamomum malabatrum were determined by GC and GCMS. ${ }^{5}$

39 compounds, constituting $95 \%$ of the oil, were identified in the leaves. Major chemical constituents of the leaf oil were Caryophyllene (28.6\%), Cinnamyl acetate (15.1\%), Bicyclogermacrene (14.4\%) and Benzyl benzoate (8.5\%). 28 compounds, representing $98 \%$ and $97 \%$ of the oil, were identified in the petioles and shoots, respectively, whereas in the oil of the terminal shoots 34 compounds, accounting for $97 \%$, were identified. The essential oils of the petiols, shoots and terminal shoots were dominated by linalool (77.8-79.4\%). In the below figures from figure 2 to figure 14 different chemical constituents structures are given.

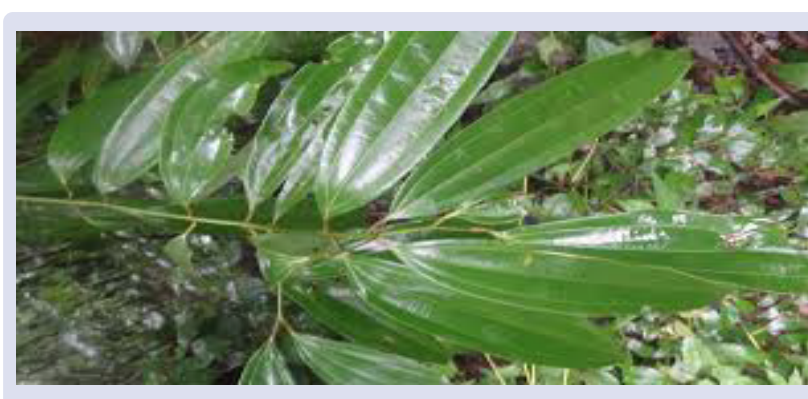

Figure 1: Leaves of Cinnamomum malabatrum.
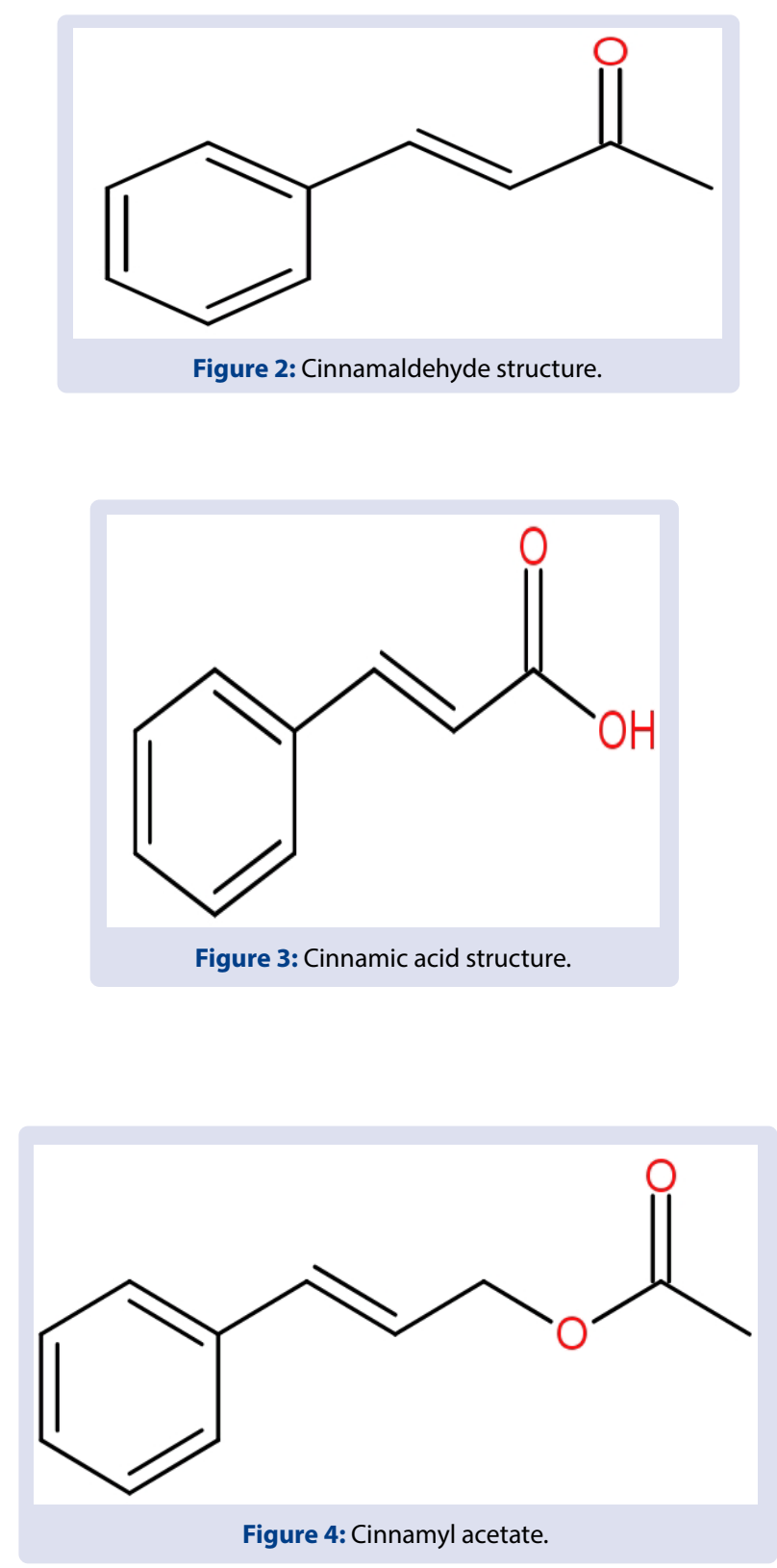

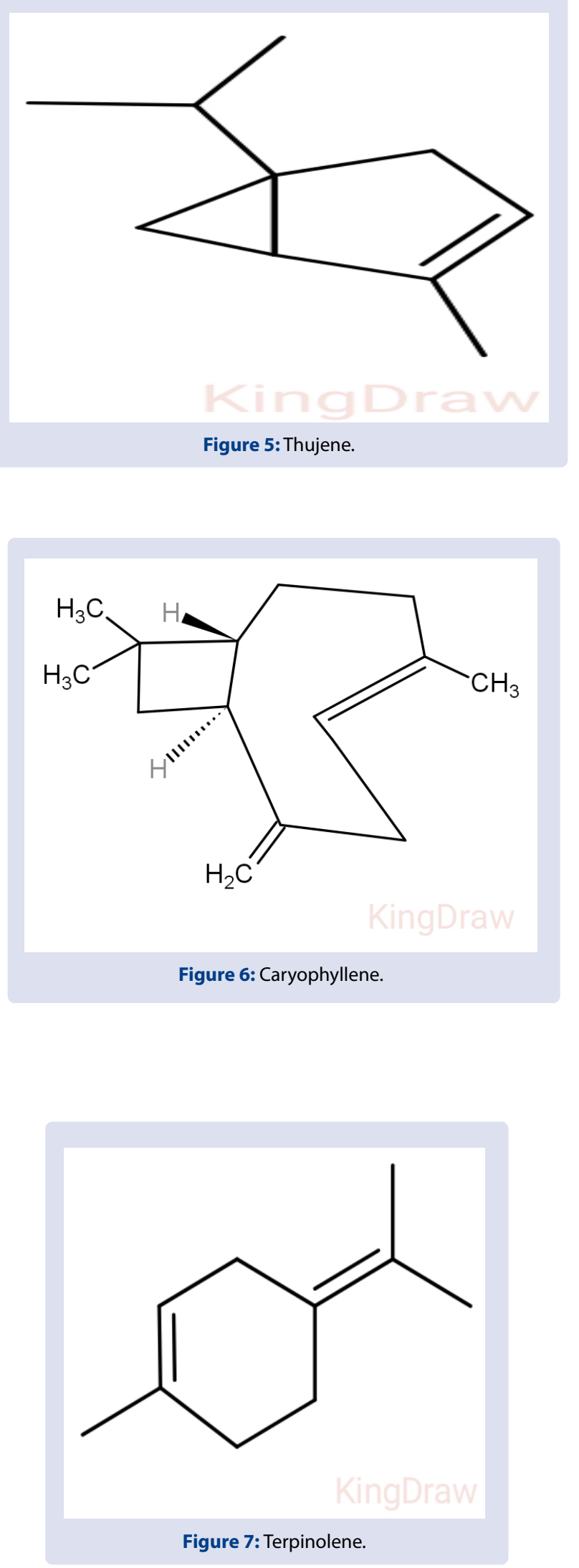

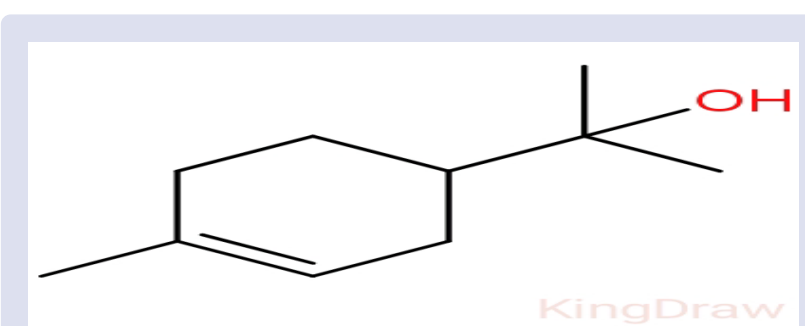

Figure 8: Alpha terpineol.
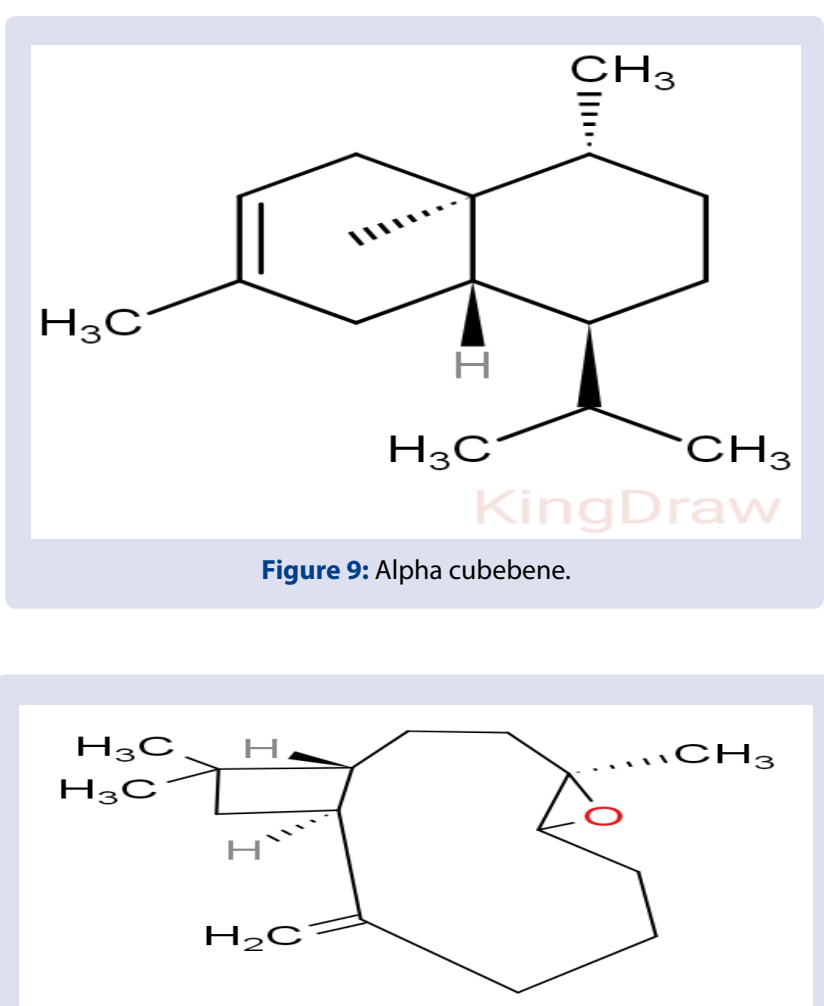

Figure 10: Caryophyllene oxide.

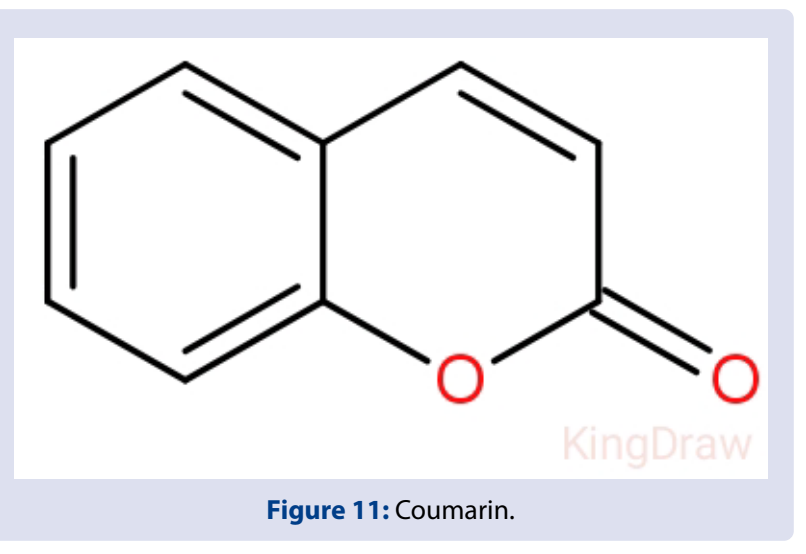


<smiles>O=C1CC(O)C(c2cccc(O)c2O)OC1=CC1c2c(O)cc(O)cc2OC2(c3ccc(O)c(O)c3)Oc3cc(O)cc(c31)C2O</smiles>

Figure 12: Prcyanidin type -a polymer.
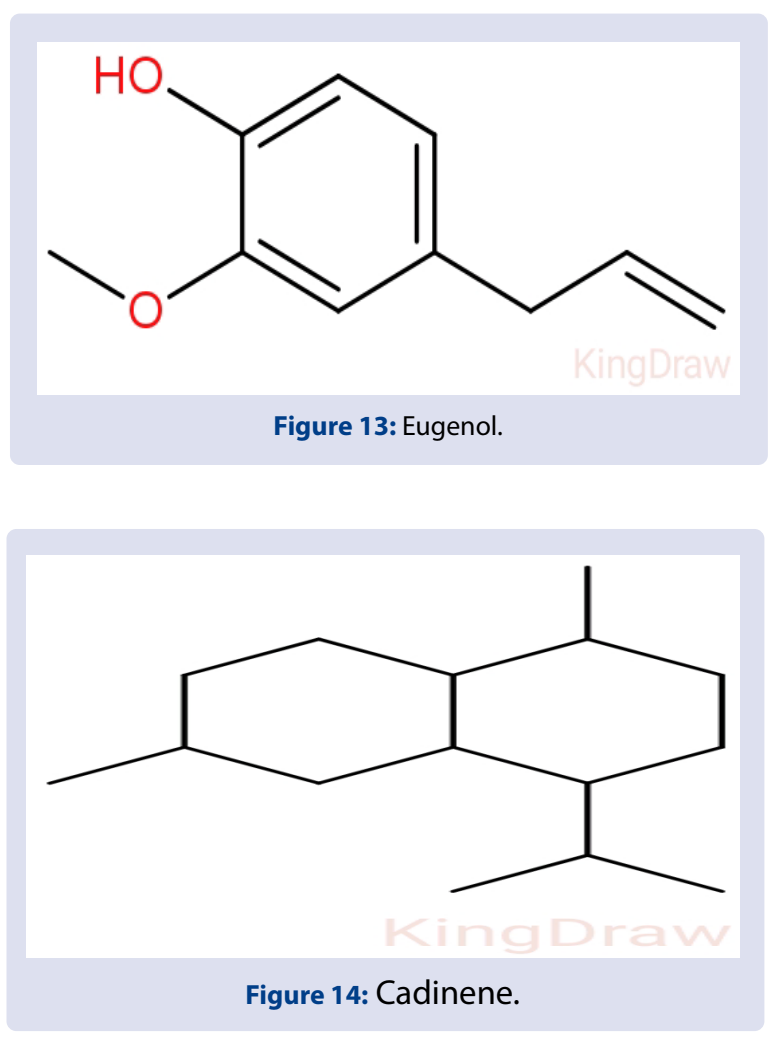

\section{LITERATURE REVIEW}

1.Amresh et al -evaluated the antidiarrhoeal activity of Cinnamomumtamala leaves extract. The hydroalcoholic extract (50$200 \mathrm{mg} / \mathrm{kg}$, p.o.) of Cinnamomumtamala exhibited dose dependent increase within the entire number of feces (control 70, reduced to 2949) and $30.7-57.9$ percentage inhibition is cathartic induced diarrhoea in rats. However, Cinnamomumtamala significantly reduced the lipid peroxidation and inhibited the decrease in antioxidant enzymes levels (superoxide dismutase and catalase) in gut on prior administration to cathartic induced fluid accumulation.

2.Yadav et al studied the antidermatophytic activity of oil of Cinnamomum as herbal ointment for the cure of dermatomycosis. The oil of Cinnamomumtamala was found to exhibit absolute antidermatophytic activity against two ring worm fungi viz. Microsporumaudouinii and Trichophytonmentagrophytes. The ointment of oil prepared in polyethylene glycol showed pronounced efficacy as herbal agent in cure of induced dermatomycosis of guinea pigs.

3.Ahmed et al studied the oil constituents of the species Cinnamomumtamala. The water distilled oil of leaves was analyzed by GC-MS. 63 compounds, representing $94.3 \%$ of the oil were identified. Linalool (13.4\%), caryophyllene oxide (10.3\%) and B- caryophyllene (25.3\%) were the foremost constituents.

4. Sorabh KA et al-(2013) reported the anticancer effect of Cinnamomum malabatrum on Daltons Lymphoma Ascites (DLA) cell lines. Aqueous and alcoholic extracts $(625 \mathrm{mg} / \mathrm{kg}$ and $500 \mathrm{mg} / \mathrm{kg} \mathrm{b} \mathrm{wt})$ were tested in DLA induced albino male rats. Parameters such as solid tumour volume, peritoneal cell count and body weights were measured. Both the extracts showed a significant reduction in decreasing the solid tumour volume, an increase in peritoneal cell count, and body cell weight. In conclusion, the Cinnamomum malabatrum bark shows good anticancer activity.

5. Pape Gowda et al- studied the structure of a new arabinoxylan from the bark of Cinnamomuminers. Two polysaccharide fractions, water- soluble (24\%) composed of xylose and - arabinose, and alkali soluble (15\%) composed of -arabinose, - xylose and - glucose, have been isolated from the delignified bark of Cinnamomuminers. The water soluble fraction gave an arabinoxylan (60\%) composed of arabinose and -xylose in the molar ratio 1.45:1.100. Methylation analysis, together with the isolation of the oligosaccharide 3-O-alphaxylopyranosyl - arabinose, 4- O- $\beta$ - xylopyranosyl- xylose, and xylopyranosyl - $(1 \rightarrow 4)-\mathrm{O}-\beta$ - xylose. After partial hydrolysis with acid, suggested that the polysaccharide contained a backbone of (1-4) linked B- xylosyl residues each of which was substituted both at O-2 and O-3 with -arabinofuranosyl groups. Very mild hydrolysis with acid gave a degraded polysaccharide, containing $10 \%$ of arabinose and $90 \%$ of xylose, which was essentially a (1-) linked B- xylan carrying a limited number of branches at O-2 and O-3. These result together with those from periodate oxidation and Smith degradation studies support the proposed structure.

6. Packiaraj R et al - Studied Antimicrobial and cytotoxic activities of entophytic fungus Colletotrichumgloeosporioidesisolated from endemic tree Cinnamomum malabatrum. Studies in Fungi.

7.Koppala Narayana Sunil Kumar et al - evaluated Chemical identity of C. Malabatrum was established in comparison with the official drug. Leaves of C. Malabatrum showed marked distinction in physicochemical and volatile oil composition which will serve as markers to differentiate it from C. tamala; the official source of tamalapatra. Though Though physic chemical constants will serve the purpose of standardization, volatile oil composition was found to be a diagnostic test for the differentiation of was found to C. Malabatrum from C. Tamala.

\section{REFERENCES}

1. Koppala Narayana Sunil Kumar, Maheshwari Rajalekshmi, Billadi Sangeetha, Basavaiah Ravishankar, Raghuveera. Chemical examination of leaves of Cinnamomum malabatrum Blume sold as Tamalapatra. Pharmacognosy journal. 2012:11-5

2. Aravind $R$, Bindu AR, Bindu K, Kanthlal S, AnilKumar B. AntiInflammatory Evaluation of the Cinnamomum malabatrum (Burm. F). Blume Leaves using Carrageenan Induced Rat Paw Oedema Method. Research J Pharm Tech. 2013;6(7):746-8.

3. Salish JM, Hrideek TK, Sujanapal P. Shade tree composition in the cardamom plantations of the Cardamom Hill Reserve area, Western Ghats, India. Prospects in Forestry and Agriculture. 2015:119-21.

4. Simi George, Veena R. In vitro and in vivo studies of the immunomodulatory effect of Cinnamomum malabatrum on female wistar rats. 2018;6:867-77. 
5. Ramamoorthy Ananthakrishnana, Ettickal S, Santhosh Kumar B, Koranappallil B, Ramesh kumara. Comparative chemical profiles of essential oil constituents of eight wild cinnamomum species from the Western Ghats of India. 2018:621-5.

6. Annegowda HV, Gooi TS, Awang SHH, Alial NA, Mordi MN, Ramanathan S, Mansor SM. Evaluation of analgesic and antioxidant potency of various extracts of Cinnamomuminers bark. International Journal of Pharmacology .2012:198-203.
7. Sorab Kumar agarwal, RC Chipa, KC Samanta Suresh. Anticancer activity of Cinnamomum malabatrum against Dalton's carcinoma. International Journal of Research in Pharmacology \& Pharmacotherapeutics. 2013:315-9.

8. Akanksha Rani, Chitra Pande, Geeta Tewari, Kiran Patni. A Review on Aroma profile of Cinnamomum species in North and North east India. 2017;6:200-21.

9. Thilagavathi T, Arvindganth R, Vidhya D, Dhivya R. Preliminary Phytochemical screening of different Solvent mediated Medicinal plant extracts evaluated. International Research Journal of Pharmacy. 2015:246-8.

\section{GRAPHICAL ABSTRACT}
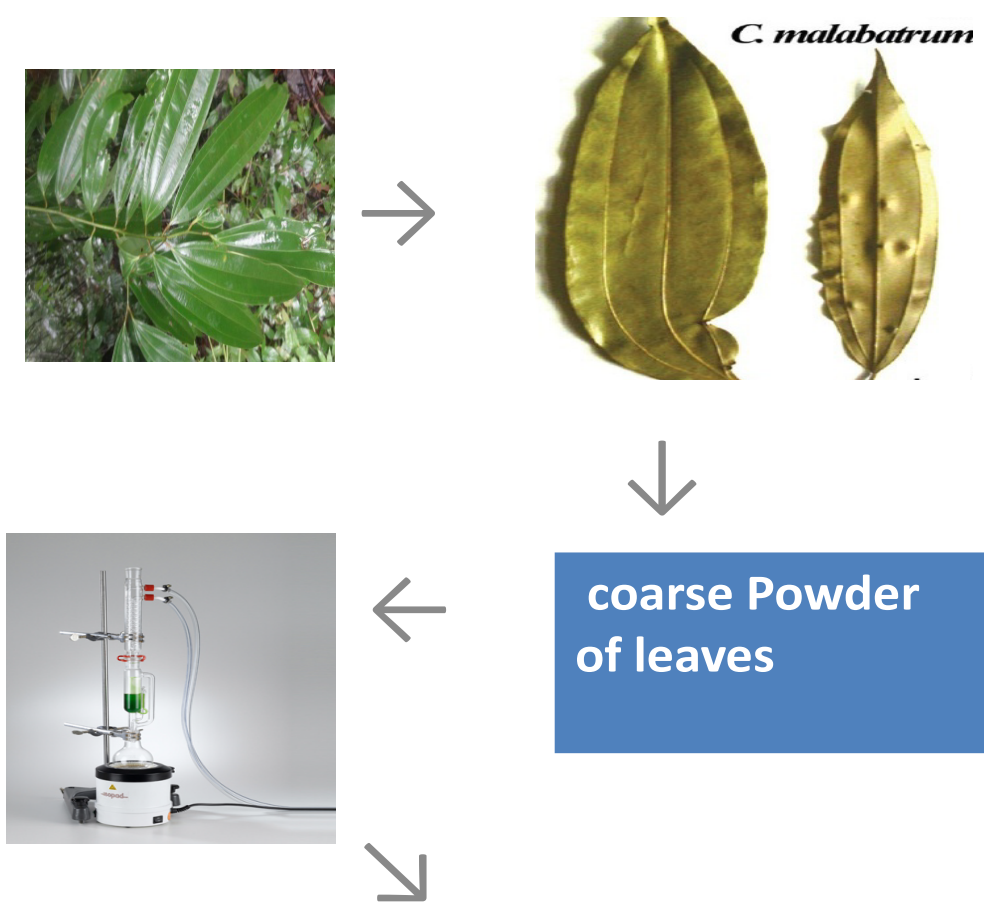

\section{coarse Powder of leaves}

\section{Alkaloids,Gycosides,Tannins,Flavono ids,Steroids, Phenols, Carbohydrates, Proteins}

\section{ABOUT AUTHORS}

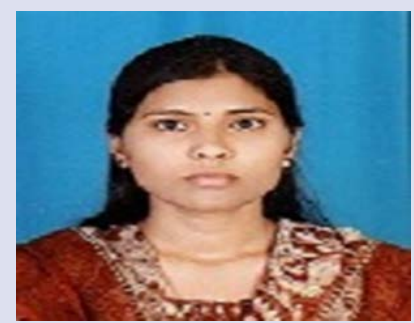

\section{Duguta Tirumala}

she is a Research scholar of Department of Pharmaceutical Chemistry and Analysis, School of Pharmaceutical Sciences, Vels Institute of Science, Technology and Advanced Studies, Pallavaram, Chennai - 600 117, Tamil Nadu, India. Research Areas of Interest Medicinal Chemistry, Phyto chemistry. 


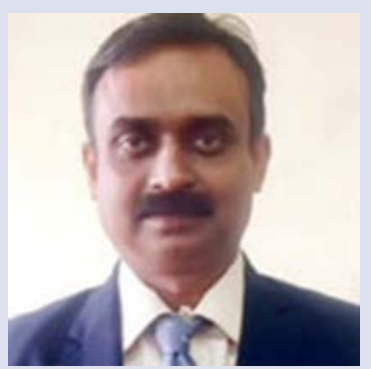

\section{Dr. Binoy Varghese Cheriyan}

He is a Professor of Department of Pharmaceutical Chemistry and Analysis, School of Pharmaceutical Sciences, Vels Institute of Science, Technology and Advanced Studies, Pallavaram, Chennai - 600 117, Tamil Nadu, India.

Area of Specialization: Pharmaceutical Chemistry, Design, Synthesis, Molecular Modeling, and Target based drug design \& docking studies on drugs acting on central nervous system.

Cite this article: Duguta T, Cheriyan BV. An Introduction and Various Phytochemical Studies of Cinnamomum Malabatrum: A Brief Review. Pharmacog J. 2021;13(3): 792-7. 